\title{
Bioremediation of polyaromatic hydrocarbons (PAHs) using rhizosphere technology
}

\author{
Sandeep Bisht ${ }^{1}$, Piyush Pandey ${ }^{2}$, Bhavya Bhargava ${ }^{3}$, Shivesh Sharma ${ }^{4}$, \\ Vivek Kumar ${ }^{5}$, Krishan D. Sharma ${ }^{6}$ \\ ${ }^{1}$ Department of Molecular Biology and Biotechnology, VCSG College of Horticulture, \\ Uttarakhand University of Horticulture \& Forestry, Uttarakhand, India. \\ ${ }^{2}$ Department of Microbiology, Assam University, Silchar, India. \\ ${ }^{3}$ Department of Floriculture \& Landscaping Architecture, VCSG College of Horticulture, \\ Uttarakhand University of Horticulture \& Forestry, Uttarakhand, India. \\ ${ }^{4}$ Department of Biotechnology, National Institute of Technology, Allahabad, India. \\ ${ }^{5}$ Amity Institutite of Microbial Technology, Amity Univeristy, Noida, India. \\ ${ }^{6}$ VCSG College of Horticulture, Uttarakhand University of Horticulture \& Forestry, Uttarakhand, India.
}

Submitted: December 24, 2013; Approved: June 6, 2014.

\begin{abstract}
The remediation of polluted sites has become a priority for society because of increase in quality of life standards and the awareness of environmental issues. Over the past few decades there has been avid interest in developing in situ strategies for remediation of environmental contaminants, because of the high economic cost of physicochemical strategies, the biological tools for remediation of these persistent pollutants is the better option. Major foci have been considered on persistent organic chemicals i.e. polyaromatic hydrocarbons (PAHs) due to their ubiquitous occurrence, recalcitrance, bioaccumulation potential and carcinogenic activity. Rhizoremediation, a specific type of phytoremediation that involves both plants and their associated rhizospheric microbes is the creative biotechnological approach that has been explored in this review. Moreover, in this review we showed the significance of rhizoremediation of PAHs from other bioremediation strategies i.e. natural attenuation, bioaugmentation and phytoremediation and also analyze certain environmental factor that may influence the rhizoremediation technique. Numerous bacterial species were reported to degrade variety of PAHs and most of them are isolated from contaminated soil, however few reports are available from non contaminated soil. Pseudomonas aeruginosa, Pseudomons fluoresens, Mycobacterium spp., Haemophilus spp., Rhodococcus spp., Paenibacillus spp. are some of the commonly studied PAH-degrading bacteria. Finally, exploring the molecular communication between plants and microbes, and exploiting this communication to achieve better results in the elimination of contaminants, is a fascinating area of research for future perspective.
\end{abstract}

Key words: PAH, bioremediation, rhizoremediation, enzyme, plant microbe pair.

\section{Introduction}

Increase in industrialization over the last century has led to elevated releases of anthropogenic chemicals into the environment. Prevalent contaminants include petroleum hydrocarbons (PHCs), polycyclic aromatic hydrocarbons (PAHs), halogenated hydrocarbons, pesticides, solvents, metals, and salt. There resulting stresses on human and ecosystem health are well documented (CCME, 2001). Polya- romatic hydrocarbons (PAHs) have been identified as hazardous chemicals by different State and Central Pollution Control Boards, because of their toxic, carcinogenic and mutagenic effects on living body. At present, hydrocarbon fuels (mainly diesel) contain an excessive quantity of PAH, causing abundant distribution of the same in the ecosphere (Ruma et al., 2007). They occur colorless, white/pale yellow solids with low solubility in water, high melting and

Send correspondence to S. Bisht. Department of Molecular Biology and Biotechnology, VCSG College of Horticulture, Uttarakhand University of Horticulture \& Forestry Bharsar, 246123 Pauri, India. E-mail: sandeepmicro83@gmail.com. 
boiling points and low vapour pressure. The physiochemical properties of some PAH given in (Table 1). These compounds enter the environment in many ways like incomplete combustion of organic materials arising from natural combustion such as forest fires and volcanic eruptions, but mainly it spread through anthropogenic activities like industrial production, transportation, refuse burning, gasification and plastic waste incineration. Release of residual PAH in air causes serious hazards to human for example, phenanthrene had been reported to affect human skin as it act as a photo sensitizer and mild allergen (Fawell and Hunt, 1988). In soil PAHs also sorbs to organic-rich sediments and in water ecosystem it accumulate in fish and other aquatic organisms, and may be transferred to humans through seafood consumption (Meador et al., 1995).

PAHs has been divided into two category i.e. lowmolecular weight (LMW) PAHs (two or three rings) which are relatively volatile, soluble and more degradable than are the higher molecular weight compounds and other were high molecular weight (HMW) PAHs (four or more rings) which sorbs strongly to soils and sediments and are more resistant to microbial degradation because of it's high molecular weight and hydrophobicity, while these PAHs were also toxic to bacteria cells (Sikkema et al., 1995). The ability of microbes to degrade oil components was already recognized at the start of the twentieth century and mainly bacteria were isolated from oil contaminated sites which able to degrade PAH [Cerniglia and Heitkamp, 1987; Juhasz and Naidu, 1996; Wilson and Jones, 1993) while bacteria from non contaminated soil was also found which have the ability to degrade PAH (Bisht et al., 2010). The concentration of PAHs in the environment varies widely, depending on the level of industrial development, proximity of the contaminated sites to the production source and the mode of PAH transport. Kanaly and Harayama (Kanaly and Harayama, 2000) reported that in soil and sediment PAHs concentrations varies from $1 \mu \mathrm{g} / \mathrm{kg}$ to over $300 \mathrm{~g} / \mathrm{kg}$.
In rhizorermediation technique the rhizosphere microbial communities were used for biodegradation of pollutants. Earlier, rhizospheric and endophytic bacteria were also reported for rhizoremediation of PAH using Populus sp. as an inoculation system in soil (Bisht et al., 2010; 2014). However, as comparison to bioaugmentation, microbe-assisted phytoremediation i.e. rhizoremediation, appears to be particularly effective for removal and/or degradation of organic contaminants from impacted soils, particularly when used in conjunction with appropriate agronomic techniques (Zhuang et al., 2007) because the chemical condition of the rhizosphere differs from bulk soil as a consequence of various processes induced by plants roots as well as by rhizobacteria (Marschner, 2001). The synergistic effect of plant roots and rhizospheric microbial communities like secretion of organic acids followed by reduction in soil $\mathrm{pH}$, production of siderophores, phytochelains, amino acids and 1-Aminocyclopropane-1-carboxylate (ACC) deaminase by plant growth promoting rhizobacteria (PGPR) were also effective for ecorestoration of polluted site as clearly depicted in (Figure 1). Rhizoremediation defined as the degradation of recalcitrant pollutants by bacteria in the rhizosphere is an attractive process since plant roots provide a large surface area for a significant population of bacteria and transport the root-colonizing, remediating microorganism to pollutants 10 to $15 \mathrm{~m}$ deep in the soil (Kingsley et al., 1994). Apart from these beneficial effects of rhizormediation over bioremediation, rhizobacteria have considerable biotechnological potential to improve the applicability and efficiency of remediation of pollutants (Weyens et al., 2009a).

The roots supply nutrients like amino acids, carbohydrates, and organic acids (Anderson et al., 1993; Kravchenko et al., 1997) so no exogenous carbon source must be added, and they may also supply bacteria with cofactors required for the activation of bacterial enzymes involved in the pollutant degradation pathway. With the wide range of catabolic reactions mediated by microbes and its enzymes,

Table 1 - Physico- chemical properties of PAH.

\begin{tabular}{|c|c|c|c|c|c|c|c|c|}
\hline S. No. & Name & M.F. & $\begin{array}{l}\mathrm{CAS} \\
\text { registry } \mathrm{No}^{\mathrm{a}}\end{array}$ & $\begin{array}{l}\text { B.Pt. } \\
\left({ }^{\circ} \mathrm{C}\right)^{\mathrm{a}}\end{array}$ & $\begin{array}{l}\text { M.Pt. } \\
\left({ }^{\circ} \mathrm{C}\right)^{\mathrm{a}}\end{array}$ & $\begin{array}{c}\text { V.P. } \\
\left(\mathrm{Pa} \text { at } 25^{\circ} \mathrm{C}\right)\end{array}$ & $\begin{array}{l}\text { Aqueous solubility } \\
\qquad(\mathrm{mg} / \mathrm{L})^{\mathrm{b}}\end{array}$ & $\begin{array}{r}\text { IARC }^{\mathrm{C}} \\
\text { group }\end{array}$ \\
\hline 1 & Benzo[k] flouroanthene & $\mathrm{C}_{20} \mathrm{H}_{12}$ & 207-08-09 & 480 & 215.7 & $5.2 \times 10^{-8}$ & - & 28 \\
\hline 2 & Anthracene & $\mathrm{C}_{14} \mathrm{H}_{10}$ & $120-12-7$ & 342 & 216.4 & $1 \times 10^{-3}$ & 0.015 & 3 \\
\hline 3 & Benzo[b] flouroanthene & $\mathrm{C}_{20} \mathrm{H}_{12}$ & $205-99-2$ & 481 & 168.3 & $6.7 \times 10^{-5}$ & - & 28 \\
\hline 4 & Flouroanthene & $\mathrm{C}_{16} \mathrm{H}_{10}$ & $206-44-0$ & 375 & 108.8 & $1.2 \times 10^{-3}$ & 0.25 & 3 \\
\hline 5 & Napthalene & $\mathrm{C}_{10} \mathrm{H}_{8}$ & $91-20-3$ & 218 & 80.2 & 11 & 30 & n.e \\
\hline 6 & Phenanthrene & $\mathrm{C}_{14} \mathrm{H}_{10}$ & $85-01-8$ & 340 & 100.5 & $2 \times 10^{-2}$ & $1-2$ & 3 \\
\hline 7 & Benzo[ghi] perylene & $\mathrm{C}_{22} \mathrm{H}_{12}$ & $191-24-2$ & 500 & 277 & $6 \times 10^{-8}$ & - & 3 \\
\hline 8 & Benzo[e] pyrene & $\mathrm{C}_{20} \mathrm{H}_{12}$ & $192-97-2$ & 493 & 178.7 & $4 \times 10^{-7}$ & - & 3 \\
\hline 9 & Pyrene & $\mathrm{C}_{16} \mathrm{H}_{10}$ & $129-00-0$ & 150.4 & 393 & $6 \times 10^{-4}$ & $0.12-0.18$ & 3 \\
\hline
\end{tabular}

a: (WGPAH, 2001); b: (Mackay et al., 1991); c: (IARC, 1983). 


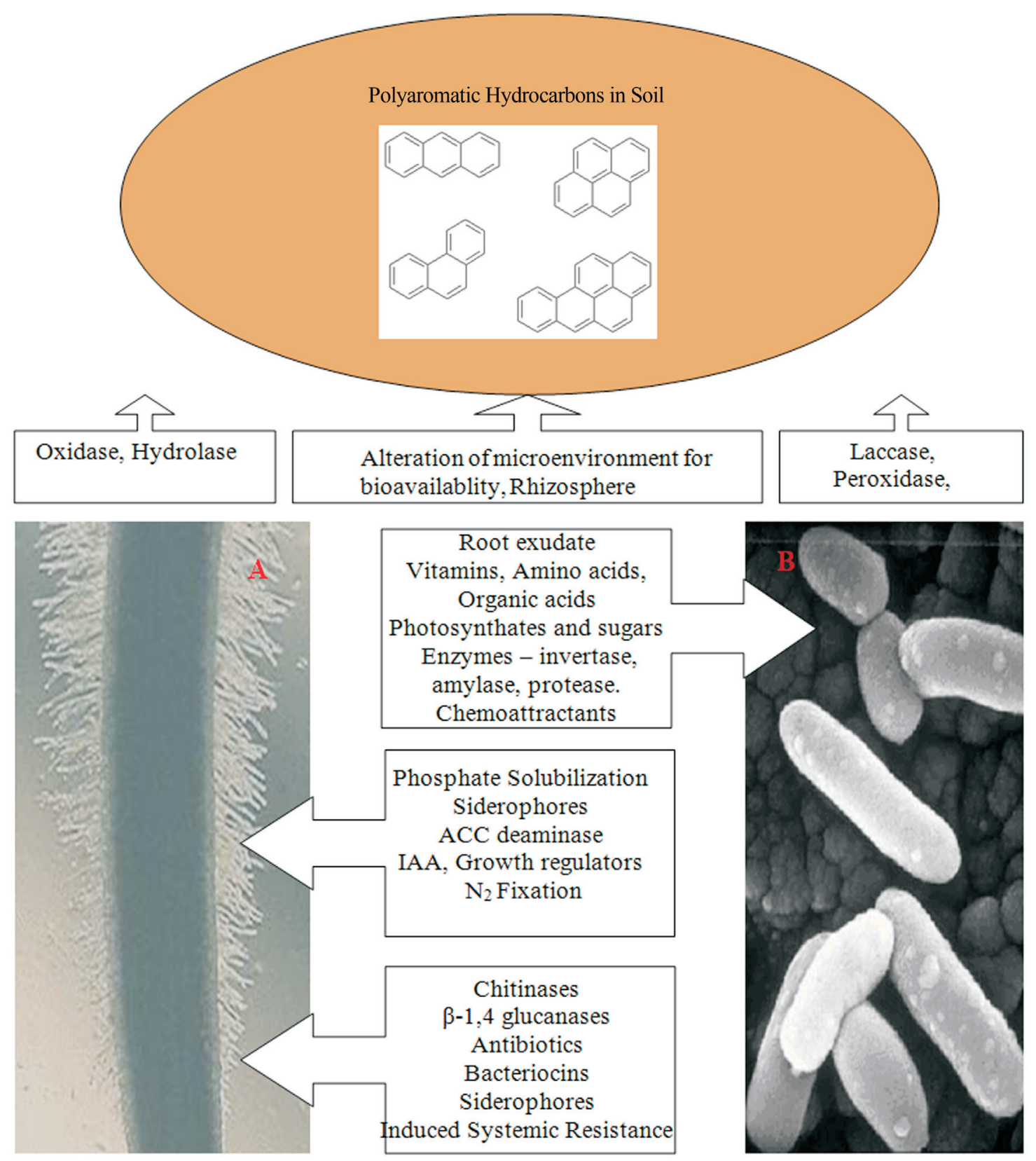

Figure 1 - Synergistic effect of plant root and rhizobacteria in biodegradation of polyaromatic hydrocarbon contaminated soil. (A) Factor affecting rhizoremediation of PAH by plant roots: support microbial growth at the root surface as well as in the rhizosphere with the help of root exudates which provide nutrients vitamins, sugars, organic acid, enzymeslike protease, amylase etc which act as a chemoaatractant for bacteria. (B) PGPR, plant growth promoting rhizobacteria; provide growth hormone (IAA), minerals, nutrient cycling, ACC deaminase and various enzymes for bioprotecting from fungal pathogen to roots.

bioremediation techniques till date are the most economical and ecofriendly strategies for removal of organic and inorganic contamination. Although rhizoremediation occurs naturally, it can also be optimized, by deliberate manipulation of the rhizosphere. It can be accomplished by using suitable plant-microbe pairs. There may be either combinations of plants and plant growth promoting rhizobacteria (PGPR), or combinations of plants and contaminantdegrading microbes. Kuiper et al. (2004) described the pair of a grass species with a naphthalene degrading microbe which protected the grass seed from the toxic effects of naphthalene, and the growing roots exploited with the naphthalene degrading bacteria into soil. In rhizodegradation of PAHs, other main processes were also involved as the rhizoremediation of PAH in which plant root system aerates the soil, distributes the rhizobacteria through soil and penetrates impermeable soil layers, solubilizing the pollutants in soil-water and making it bio available to the 
plant and microbes. Researchers have exploited this symbiotic relationship for rhizoremediation of hazardous and xenobiotic compounds like (PCBs) (Narasimhan et al., 2003), (PAHs) (Shah et al., 1994; Bisht et al., 2014), (TCE) (Walton and Anderson, 1990). As reviewed by Mackova et al. (2006), suggested that rhizoremediation can be successfully used for restoration of contaminated sites by choosing right type of plant cultivar with right rhizobacteria or by inoculating efficient rhizobacterial strains on plant seeds/roots. Mechanical injection of contaminated sites with pollutant-degrading bacteria has been used to clean polluted sites in an inexpensive and less labor-intensive way than the removal and/or combustion of polluted soils (Timmis and Pieper, 1999). However, bioaugmentation technique is limited for a number of reasons. Firstly, high beneficial bacterial population numbers cannot be maintained, presumably because of low nutrient availability and low energy yield from the degradation of the polluting compounds (Ramadan et al., 1990), while the addition of nutrients though increase bacterial activity, yet this method is expensive and too labor-intensive for larger contaminated sites. Secondly, injected microbes cannot penetrate less porous layers and do not reach the deeper layers of the soil, and third, the plasmids that usually encode the ability to degrade pollutants can be lost in soil. The use of plants as bio-injectors of pollutant-degrading bacteria has a number of advantages such as a highly branched, deep root system that can be used as a vector for the more-or-less homogeneous bio-injection of root-colonizing bacteria and for the penetration of layers normally not permeable to bacteria. Additionally, because roots can exude up to $35 \%$ of their photosynthate as exudate carbon (Gregory and Atwell, 1991) and release oxygen or provide better redox conditions (Bodelier et al., 2000) which can become limiting for bacterial growth in soil, the rhizosphere is a good environment for bacteria to survive and proliferate (Brazil et al., 1995; Liste and Alexander, 2000; Nichols et al., 1997; Yee et al., 1998). In this review, we tried to focus on the importance of rhizoremediation technique over other remedial strategies and use of plant -microbe pair with biodegradation of PAH pollutants from soil.

\section{Bioremediation by Microbes in Polluted Sites}

Growing awareness of the harmful effects of PAH pollutants to the environment and human health has led to a marked increase in research into various strategies that might be used to clean up contaminated sites. Many conventional decontamination methods are expensive partially because of the cost of excavating and transporting large quantities of contaminated materials for treatment, such as soil washing, chemical inactivation, and incineration (Chaudhry et al., 2005). The increasing costs and limited efficiency of these traditional physicochemical treatments, the biological treatment of soil have come into existence of alternative technologies for in situ applications (Singh and
Jain, 2003). The term bioremediation refers to the use of living organisms to degrade environmental pollutants (Dua et al., 2002; Barea et al., 2005).

\section{Natural Attenuation/Intrinsic Bioremediation: A Natural Process for Biodegradation of Pollutants}

The simplest form of bioremediation is natural attenuation (NA) or bioattenuation, during which the indigenous microbial populations degrade recalcitrants or xenobiotics compounds based on their natural metabolic processes (Kuiper et al., 2004; Widada et al., 2001). According to the Environmental Protection Agency in the United States (USEPA, 1999) NA or intrinsic bioremediation processes include a variety of physical, chemical, and biological processes that act to reduce the mass, toxicity, mobility, volume, or concentration of contaminants. These processes include aerobic and anaerobic biodegradation, dilution, sorption, volatilization decay, and chemical or biological stabilization, transformation of contaminants (Gentry et al., 2004). When time is not a limiting factor, NA can be well being applied on sites with low environmental pollutants, where no other remedial techniques are applicable (Kuiper et al., 2004). As a limiting factor, no other microbes with suitable catabolic genes might not be available on the contaminant sites.

\section{Bioaugmentation by Modified Microbes}

Bioaugmentation is a method to improve degradation and enhance the transformation rate of xenobiotics by introducing either wild type or genetically modified microbes into soil (Kuiper et al., 2004). A bioinoculant is a beneficial, natural microbe introduced into soil for e.g. by bacterization of plants seeds. The laboratory scale results of seeding microbes for degradation of soil pollutants have been vague (Kuiper et al., 2004). Problems associated with bioaugmentation (Gentry et al., 2004) observe that the number of exogenous microorganisms decreases shortly with the increase in time of inoculation after addition on to the site. There are several reasons for the death of introduced organisms, including both abiotic and biotic stresses; it may include fluctuations or extremes in temperature, water content, $\mathrm{pH}$, and nutrient availability, along with potentially toxic pollutant levels in contaminated soil. In addition, the added microorganisms almost always face competition from non indigenous bacteria (NIB), limited nutrients, along with antagonistic interactions including antibiotic production by competing organisms, and predation by protozoa, bacteriophages and fungi. Rahman et al. (2002) suggested that co-inoculation of a consortium of bacteria, each with different catabolic degradation route, involved in biodegradation of a certain pollutant is often found to be more efficient than the introduction of one individual strains with the complete catabolic pathway. More- 
over maximum degradation pathways were reported from Mycobacterium sp. because of its exceptional ability to degrade a great variety of low and high molecular weight $\mathrm{PAH}$ and it follows mainly oxidative and hydroxylation mechanism (Kim et al., 2004). Intermediates metabolites were separated and identified via HPLC, UV and analyzed using mass and NMR spectral data.

\section{Phytoremediation: As a Remedial Strategy for PAH Pollutants}

Phytoremediation is mean to be the use of plants and their associated microbes for environmental cleanup (Salt et al., 1998; Singh and Jain, 2003). Phytoremediation has potential versatility to treat a diverse range of hazardous polllutants, may be used in much large scale clean-up, as it is environmental friendly ecotechnology and is easy to implement to soil pollutants. This non invasive method is also sustainable and can be visually attractive technology for eco restoration of polluted sites. Earlier, to this phytoremediation field trials, extensive research was performed in vitro condition and many of the work explored the effects of plants on removal of contaminants from spiked soil and soil excavated from contaminated sites (Huang et al., 2004) and most of these experiments provided valuable insights into the specific mechanisms of phytoremediation of organic contaminants (Reed and Glick, 2005). Organic pollutants that have been successfully phytoremediated include organic solvents such as TCE (trichloroethylene), herbicides such as atrazine, explosives such as TNT (trinitrotoluene), PHC, BTEX (mono aromatic hydrocarbons) and PAHs, the fuel additive MTBE (methyl tertiary butyl ether), and PCBs (polychlorinated biphenyls) (Pilon-Smits, 2005) Along with these Pilon-Smits (2005), also remediate some inorganic pollutants such as nitrate, phosphate, plant trace elements like $\mathrm{Cr}$ and $\mathrm{Zn}$, heavy metals, plant macronutrients and radioactive isotopes. With these experiments allowed researchers to explore methods for overcoming contaminant stress, without the confounding effects of environmental condition such as weather and nutrient limitation. Earlier, Boyajian and Carreira (1997) reported that plants can have more than 100 million miles of roots per acre, which suggests great potential for phytoremediation in natural environments but Harvey et $a$. (2002) conclude that the in phytoremedition problem lies in removal of high concentrations of contaminants which tend to inhibit plant growth, including root growth, or due to oxidative stress. The resulting stress will limit the rate of phytoremediation in situ condition (Huang et al., 2005). The main application for phytoremediation has so far been successful to remove toxic heavy metals from soil (Chaudhry et al., 2005; Salt et al., 1998). The demerits related to this strategy is that it needs longer time for remediation due to slow growth of plants, limited by climate change and soil characteristics, the pollutants may enter onto ground again by litter effects and root exudates may increase the solubility of pollutants to increase their distribution rates in soil environment (Pilon-Smits, 2005). However, there is a growing extensive research in broadening applications of this eco technology to remove/degrade organic pollutants in the environment.

\section{Rhizoremediation: The Use of Beneficial Plant-Microbe Interaction (PMI) for Ecorestoration of Polluted Sites}

In many of the studies an important contribution to the degradation of pollutants is ascribed to microbes, without the microbial contribution, phytoremediation alone may not be a viable technology for many PAH (Chaudhry et al., 2005). Rhizoremediatioin term consists of both phytostimulation and rhizodegradation describing the beneficial interaction of both the plant and the rhizobacteria. The first study towards degradation of compounds in the rhizosphere was mainly focused for herbisie and pesticides (Jacobsen, 1997). Today, there are many reports regarding the rhizoremediation of PAH were studied and many of them listed in (Table 2) but the composition of microbial population were not analyzed in details. Plant-microbial interactions in the rhizosphere offer very useful means for remediating environments contaminated with recalcitrant PAH compounds (Chaudhry et al., 2005). Rhizoremediation occurs naturally for one reason i.e. of flavonoids and other compounds released by roots which can stimulate growth and activity of PAH degrading bacteria (Thoma et al., 2003; Leigh et al., 2006). Furthermore, root growth and death promotes soil aeration, which can enhance oxidative degradation of recalcitrant PAHs compounds (Leigh et al., 2002). Notably, Siciliano et al. (2003) reported that some plant species appear to increase the numbers of degradative microbes in a large volume of soil that extends beyond the rhizosphere. The success of plant species as the successful rhizoremediation might depend on its highly branched root system to harbor large numbers of bacteria, primary and secondary metabolism and establishment, survival, and ecological interactions with other organisms (Kuiper et al., 2004; Salt et al., 1998). Plant roots can act as a substitute for the tilling of soil to incorporate additives (nutrients) and to improve aeration (Kuiper et al., 2004; Aprill and Sims, 1990). Plant species belonging to the genera Populus sp. (poplar) and Salix sp. (willow) have been used successfully for rhizoremediation of PHC contaminated soils probably due to introduction of oxygen into deeper soil layers through specialized root vessels, aerenchyma (Zalesny et al., 2005). The mucigel secreted by root cells, lost root cap cells, the starvation of root cells, or the decay of complete roots provides nutrients in the rhizosphere (Kuiper et al., 2004; Lugtenberg and de Weger, 1992). In addition, plants release a variety of photosynthesis derived organic compounds (Salt et al., 1998; Pilon-Smits, 2005). These root exudates contain water soluble, insoluble, and volatile 
Table 2 - Rhizoemediation of pollutants using plant - microbe pair.

\begin{tabular}{lccc}
\hline Plants & Pollutants & Microbes & References \\
\hline Prairie grasses & PAHs & Not identified & (Aprill and Sims, 1990) \\
Prairie grasses & PAHs & Not identified & (Qiu et al., 1994). \\
Alfalfa & Pyrene, Anhracene, Phenanthrene & Not identified & (Schwab et al., 1995). \\
Sugar beet & PCBs & Psudomonas flourscens & (Brazil et al., 1995). \\
Senecus glaucus & Oil & Arthrobactor & (Radvan et al., 1995). \\
Barley & $2,4-\mathrm{D}$ & Bulkhurderia cepacia & (Jacobsen, 1997). \\
Wheat & 2 4-D & Pseudomonas putida & (Kingsley et al., 1994). \\
Grasses & Napthalene & Pseudomonas putida & (Kuiper et al., 2001). \\
Oat, lupin, rape, dl, pepper, radish, pine & Pyrene & Not identified & [Liste and Alexander, 2000). \\
Populus deltoids niger & 4-dioxane & Actinimycetes & (Schnoor et al., 1998). \\
Populus deltoides & PAH & Kurthia sp. & (Bisht et al., 2010; 2014). \\
& & Micrococcus sp. & Bacillus sp. \\
\end{tabular}

*PAHs- Polyaromatic hydrocarbons, PCBs- Polychlrinated biphenyls and 2, 4-D- 2,4-Dichlorophenoxy acetic acid.

compounds including sugars, alcohols, amino acids, proteins, organic acids, nucleotides, flavonones, phenolic compounds and certain enzymes (Yee et al., 1998; Salt et al., 1998; Kuiper et al., 2004; Anderson et al., 1993). The rate of exudation changes with the age of a plant, the availability of mineral nutrients and the presence of contaminants (Yee et al., 1998). The nature and the quantity of root exudates, and the timing of exudation are crucial for a rhizoremediation process. Plants might respond to chemical stress in the soil by changing the composition of root exudates controlling, in turn, the metabolic activities of rhizosphere microorganisms (Yee et al., 1998). Some organic compounds in root exudates may serve as carbon and nitrogen sources for the growth and long-term survival of microorganisms that are capable of degrading organic pollutants (Anderson et al., 1993; Kuiper et al., 2004; Salt et al., 1998). For instance, plant phenolics such as catechin and coumarin may serve as co-metabolites for PCBdegrading bacteria (Kuiper et al., 2004; Salt et al., 1998). Rhizomicrobial population is a major soil ecological environment for plant-microbe interactions involving colonization of different microorganisms in and around the roots of growing plants (Pandey and Maheshwari, 2007). Microbes living in the rhizosphere, rhizomicrbia, in turn, can promote plant health by stimulating root growth (regulators), enhancing water and mineral uptake, and inhibiting growth of pathogenic or other, non-pathogenic soil microbes (Kuiper et al., 2004; Pilon-Smits, 2005). Rhizomicrobial population may also accelerate remediation processes by volatilizing organics such as PAHs or by increasing the humification of organic pollutants (Salt et al., 1998). In particular, the release of oxidoreductase enzymes (e.g. peroxidase) by microbes, as well as by plant roots, can catalyze the polymer- ization of contaminants onto the soil humic fraction and root surfaces. In contrast to the limited studies of rhizoremediation (Kuiper et al., 2004), Barea et al. (2005) reviewed that beneficial plant growth promoting, rootcolonizing rhizobacterial strains (PGPR) have been extensively described for processes such as biocontrol of plant pathogens, and nutrient cycling by non symbiotic $\mathrm{N}_{2}$ - fixing bacteria and phosphate solubilizing bacteria (PSB), i.e. act as a biofertilizer. The success of beneficial processes is based on the rhizosphere competence of the microbes, which is reflected by the ability of the microbes to survive in the rhizosphere, compete for the exudate nutrients, sustain in sufficient numbers, and efficiently colonize the growing root system (Kuiper et al., 2004; Lugtenberg and de Weger, 1992). Recently, it was shown that chemotaxis by $P$. fl uorescens WCS365 toward some organic acids and amino acids (but not to sugars) present in tomato root exudates plays an important role during root colonization (Kuiper et al., 2004; de Weert et al., 2002). Another example of the importance of the efficient use of exudates was shown for $P$. putida PCL1444. The selection of this strain for survival and proliferation on grass roots coincided with very efficient use of the main organic acids and sugars from the grass root exudate and with a high expression level of its catabolic genes for naphthalene degradation during the use of these substrates (Kuiper et al., 2002; Kuiper et al., 2004). Usually, several bacterial populations degrade pollutants more efficiently than a single species/strain due to the presence of partners, which use the various intermediates of the degradation pathway more efficiently (Joint metabolism) (Pelz et al., 1999; Kuiper et al., 2004). During rhizoremediation, the degradation of a pollutant, in many cases, is the result of the action of a consortium of bacteria (Kuiper 
et al., 2004). The colonization of different niches of plant roots by different strains has also been recognized (Kuiper et al., 2004; Kuiper et al., 2001; Dekkers et al., 2000). However, very few studies report the directed introduction of a microbial strain or consortium for xenobiotic degradation activities (bioaugmented rhizoremediation), which is able to efficiently colonize the root (Kuiper et al., 2004; Kuiper et al., 2001; Ronchel and Ramos, 2001; Sriprang et al., 2002).

\section{Environmental Factor Affecting PMI in PAHs Biodegradation}

In many ways environmental factor may alter the mechanisms of rhizoremediation of PAH in soil for e.g. soil type i.e. texture, particle size, nutrients and organic matter content which can limit the bioavailability of pollutants (Walton et al., 1994). Water content in soil and wetland affect plant/microbial growth, availability of oxygen required for aerobic respiration and temperature affects the rate at which various processes take place because temperature change in the environment due to sunlight can transform parent compounds into other compounds, which may have different toxicities than original compounds. Nutrient availability to the plant can influence the rate and extent of degradation in contaminated sites. Finally, these environment factor causes degradation of certain fraction of the contaminant mixture with end result being that only the more resistant compounds remain in soil.

\section{Microbial Bioavailability of Pollutants}

With respect to the environmental factor the bioavailability of organic compounds is also utmost important factor that determines the overall success of bioremediation process (Chaudhry et al., 2005; Salt et al., 1998). It depends on the physio - chemical properties of the pollutant, soil properties, environmental conditions and biological activity (Salt et al., 1998; Pilon-Smits, 2005). Rentz et al. (2003) suggested that overcoming oxygen limitation to plants should be considered in phytoremediation projects when soil contamination exerts a high biochemical oxygen demand, such as in former oil refinery sites. Plants with aerenchyma such as reed (Phragmites australis) can release oxygen into the rhizosphere and are used for rhizoremediation (Muratova et al., 2003). Chemotaxis has been shown to promote bioavailability in bacteria isolated from a polluted. rhizosphere that degrade PAHs (Paul et al., 2005; Ortega-Calvo et al., 2003). Chemotaxis is the movement of microorganisms under the influence of a chemical gradient that helps them to find optimum conditions for growth and survival (Paul et al., 2005). Similarly, Bisht et al. (2010) isolated chemotactically active rhizobacteria from the rhizosphere of $P$. deltoides which has immense importance in biodegradation of anthracene and naphthalene. In the past few years, several microbes have been reported to be chemotactic towards different environmental pollutants, for instance toluene acting as chemoattractant to Pseudomonas putida F1 (Paul et al., 2005; Parales et al., 2000). Chemotactic bacteria might be more competent for bioremediation than their non chemotactic counterparts (Paul et al., 2005).

\section{PAHs Biodegradation: Role of Microbial Diversity}

Bacteria are the class of microorganisms actively involved in the degradation of organic pollutants from contaminated sites. A number of bacterial species are known to degrade PAHs. Most of them, representing biodegradation efficiency, are isolated from contaminated soil or sediments. Long-term petrochemical waste discharge harbours bacteria capable of degrading PAH to a considerable extent. Among the PAH in petrochemical waste, Benzo (a) pyrene $(\mathrm{BaP})$ is considered as the most carcinogenic and toxic. Earlier, studies have shown that bacteria can degrade $\mathrm{BaP}$ when grown on an alternative carbon source in liquid culture experiments. Ye et al. (1996) observed a 5\% decrease in $\mathrm{BaP}$ concentration after $168 \mathrm{~h}$ during incubations with Sphingomonas paucimobilis strain EPA 505 and with the immobilization of S. paucimobilis strain EPA 505 grown on nutrient agar supplemented with glucose, resulted in significant evolution of ${ }^{14} \mathrm{CO} 2(28 \%)$ indicating hydroxylation and ring cleavage of the 7,8,9,10-benzo ring. Aitken et al. (1998) isolated 11 strains with the ability to degrade BaP from a variety of contaminated sites (oil, motor oil, wood treatment, and refinery) and they were mainly from five species of Pseudomonas, Agrobacterium, Bacillus, Burkholderia and Sphingomonas species The other bacteria like Rhodococcus sp., Mycobacterium, and mixed culture of Pseudomonas and Flavobacterium species were also reported to degrade $\mathrm{BaP}$ (Walter et al., 1991; Trzesicka-Mlynarz and Ward, 1995).

Heitkamp et al. (1988) described a bacterial isolate which was able to mineralize pyrene. Similarly, Rehmann et al. (1998) isolated a Mycobacterium spp., strain KR2 from a PAH contaminated soil of a gaswork plant, which was able to utilize pyrene as sole source of carbon and energy. The isolate metabolized up to $60 \%$ of the pyrene added $\left(0.5 \mathrm{mg} \mathrm{mL}^{-1}\right)$ within 8 days at $20{ }^{\circ} \mathrm{C}$. Earlier, also Dean-Ross et al. (2002) isolated two bacterial strains ( $M y$ cobacterium flavescens and Rhodococcus spp.) from sediments of River Grand Calumet from two different locations. Both the bacteria were found to be capable of PAH degradation with the initial reaction rates of $0.044 \mathrm{mg} \mathrm{L}^{-1}$ for the $K$ s for pyrene mineralization by $M$. flavescens and $0.470 \mathrm{mg} \mathrm{L}^{-1}$ for the $K \mathrm{~s}$ for anthracene mineralization by Rhodococcus species. Romero et al. (1998) isolated Pseudomonas aeruginosa from a stream polluted by petroleum refinery. It was found to be actively growing over high dosages of phenanthrene with comlete removal of the pollutant 
in a period of 30 days. Yuan et al. (2002) isolated six gram negative strains of bacteria from a petrochemical waste disposing site having the capacity of degrading acenaphthene, fluorene, phenanthrene, anthracene, and pyrene by $70-100 \%$ in a period of 40 days of initial treatment. Two of the six strains isolated were Pseudomons fluoresens and Haemophilus spp. while others were rod-shaped bacteria.

The first presentation of the metabiolic pathway and the enzymatic reactions resulting in mineralization of naphthalene was by Davis and Evans (1964). Since then, the degradation of PAH by microbes has been studied intensively and this ability was identified to be present in a wide variety of bacteria, fungi and algae (Cerniglia, 1997; Dagher et al., 1997; Shuttleworth and Cerniglia, 1995). The first PAH degrading bacteria were reported from oil contaminated soil by (Cerniglia and Heitkamp , 1987, Juhasz and Naidu, 1996; Wilson and Jones, 1993). Naphthalene biodegradation is the best studied of the PAHs because it is the simplest and most soluble PAH, and naphthalenedegrading microorganisms are relatively easy to isolate. Bacterial strains that are able to degrade different PAH have been repeatedly isolated, mainly from soil. These are usually gram-negative bacteria; most of them belong to the genus Pseudomonas. The biodegradative pathways have also been reported in bacteria from the genera Mycobacterium, Corynebacterium, Aeromonas, Rhodococcus, and Bacillus (Cerniglia, 1984; Annweiler et al., 2000). The tricyclic aromatic hydrocarbons are widely distributed throughout the environment. So, they have been used as model substrates in studies on the environmental degradation of PAHs, since both structures are found in carcinogenic PAHs such as benzo[a]pyrene, benz[a]anthracene and 3-ethylcholanthrene. Pure cultures and mixed cultures of bacteria isolated from fresh-water and marine environments have the ability to metabolize anthracene and phenanthrene as the sole source of carbon. Anthracene can be completely mineralized by Pseudomonas, Sphingomonas, Nocardia, Beijerinckia, Rhodococcus and Mycobacterium with the initial oxygenated intermediate being a dihydriol (Moody et al., 2001). Growth of Sphingomonas yanoikuyae JAR02 on plant root exudates and root extracts was observed along with removal of benzo[a]pyrene from solution through constitutively expressed degradative enzymes, corroborating field observations of increased PAH degradation in the rhizosphere (Aprill and Sims, 1990; Banks et al., 1999; Binet et al., 2000; Paquin et al., 2002). Hedlund and Staley (2006) found that Pseudoalteromonas strains with identical 16S rRNA gene sequences varied in the suite of PAHs that they could degrade and had likely acquired a gene coding for a naphthalene-degrading enzyme by horizontal transfer. Secondly, isolates can be identified that degrade PAHs but do not contain genes with high homology to known genes implicated in PAH degradation (Widada et al., 2002). Danne et al. (2001) reported the isolation of spore-forming, PAH-degrading bacteria and subsequent genetic studies of their degradation pathways which may lead to the discovery of novel genes involved. In addition, they evaluate the biodegradation potential of select isolates and determine if reinoculation of the rhizosphere would enhance degradation of contaminated marine sediment. Filonov et al. (2006) assessed the efficiency of the naphthalene degradation process performed by different microbial strains of the genera Pseudomonas and Burkholderia in soil model systems. Moreover, the effect of salicylate (2-hydroxybenzoic acid) on the naphthalene biodegradation process was also developed in such systems. Finally, a mathematical description of the process was also proposed to check the efficiency of degradation in field site.

Numerous studies have demonstrated the importance of the rhizosphere effect on degradation of organic contaminants. Most of these studies have examined terrestrial plants and agricultural chemicals (Arthur et al., 2000); few have looked at the influence of plant-associated microorganisms on the fate PAHs (Schwab and Banks, 1994). Many of the bacterial species and genera that we isolated have been reported to degrade PAHs previously. Few reports have been made regarding Paenibacillus and its ability to degrade PAHs. Pichinoty et al. (1986) described Bacillus gordonae sp. nov., later to be emended as $P$. validus (Heyndrickx et al., 1995) which was able to utilize $p$-hydroxybenzoate, phthalate, isophthalate, protocatechuate, trimellitate, quinate, phenol, $p$-cresol, and naphthalene. Although, Meyer et al. (1999) reported the isolation of a PAH degrading tentative Paenibacillus sp. from tar oilcontaminated soil. Bacterial strains belonging to a few genera such as Sphingomonas, Pseudomonas, and Mycobacterium have been observed to dominate $\mathrm{PAH}$ degradation in soil (Kim et al., 2004). Recently, Bisht et al. (2010, 2014) reported four bacteria and endophytic strain from non contaminated rhizospere of $P$. deltoides $a$ which able to degrade $80-90 \%$ degradation of anthracene and naphthalene as well as in PAH conducive soil. The maximum degradation pathways were reported from Mycobacterium vanbaalenii because of its exceptional ability to degrade a great variety of low and high molecular weight PAHs oxidatively in soil. Versatility of this species makes it a probable inoculants in the remediation of PAH contaminated sites (Kim et al., 2004).

\section{Enzymatic Biodegradation}

To search for catabolic genes involved in degradation of PAH, we have to correlate them with enzymes involved in degradation pathways. Mainly, enzymes involved in the degradation of PAHs are mainly oxygenase, dehydrogenase, phosphatases, $\mathrm{d} \pm$ and lignolytic enzymes (Table 3 ). These enzymes require optimum temperature ad it was reported that mostly degradative enzymes work at mesophilic temperatures and it activity decreases with very high and low temperatures. While, some of the enzymes are reported to be active even at extremes of temperatures expect, 
laccase activity was detected at $5 \mathrm{C}$. The optimum temperature is $45{ }^{\circ} \mathrm{C}$ for laccase, but its activity drops to $30 \%$ at $5{ }^{\circ} \mathrm{C}$ however, $31 \%$ activity is found at $75^{\circ} \mathrm{C}$. On the other hand, the activity of Mn-dependent peroxidase is high even at $75^{\circ} \mathrm{C}$ (Farnet et al., 2000). Enzymes also show substrate specificity but lignolytic enzymes are non-specific acting on phenolic and non-phenolic organic compounds via the generation of cation radicals after one electron oxidation (Wilson and Jones, 1993). A phthalic derivative is produced as one of the ring fission products of PAHs by bacteria (Kotterman et al., 1998). The derivatization of phthalate results into release of carbon-di-oxide or highly complex metabolites and the lignolytic enzymes and ozonation/photocatalytic oxidation also act by free radical attack on the organo pollutants (Machado et al., 2000). Thus, the intermediates of these three methods are ring opening phthalic derivatives and aliphatics such as pentadecane, hexadecane, and nonadecane. A higher dose of PAHs in the substrate may also affect the activity/rate of microbial degradation (Verrhiest et al., 2002) while studying the interaction between a PAH mixture and microbial communities in natural freshwater sediment established that PAH dose has no effect on the microbial community in sediments up to a range of $30 \mathrm{mg} \mathrm{PAH} / \mathrm{kg}$.

The PAHs had an effect at higher concentration owing to partial inhibition of the leucine-aminopeptidase activity. The $\beta$-glucosidase activity was stimulated by the organic pollutants at the same concentration. Schutzendubel et al. (1999) found that during only 3 days of incubation, Bjerkandera adusta removed $56 \%$ and $38 \%$ of fluorene and anthracene, while Pleurotus ostreatus degraded $43 \%$ and $60 \%$ of these compounds; other PAH were degraded to a lower extent. Except for anthracene in cultures of $P$. ostreatus, all PAH were removed uniformly during the cultivation time but Fluorene and anthracene were degraded faster than other PAH. The fungi produced valuable activity of manganese dependent peroxidase (MnP) but laccase was secreted only by $P$. ostreatus and was strongly induced by the addition of milled wood.The production of the oxidative enzymes did not correlate directly to the metabolism of PAH. Both fungi showed a very low activity of LiP during the degradation of PAH in the BSM medium (basal salt medium). Laccase activity was detected only in cultures of $P$. ostreatus in the BSM showed activity of MnP only at the end of cultivation. The addition of wood inhibited production of the enzyme in younger cultures and increased the activity after 27 days. The first maximum of activity was reached after 22 days in BSM cultures and BSMW (basic medium with milledwood) cultures, respectively. In cultures of both fungi, only a very low and no significant cresolase activity of the tyrosinase could be detected. In the case of $P$. ostreatus, the highest level of anthracene elimination was observed in 12-dayold cultures $(62 \%)$. A second maximum in removal of anthracene was detected after 39 days (18\%). Fluorene was degraded to a 
high degree in a 7-day-old culture (42\%) and was practically uniformly removed over the whole cultivation time. Other PAHs were degraded at an almost constant rate during the 48 days of cultivation $(1 \pm 12 \%)$. Cultures supplemented with milled wood showed much lower degradation values: only anthracene (max $23 \%$ after 17 days), fluorene $(19 \pm 30 \%)$ and partially phenanthrene $(0 \pm 8 \%)$ were degraded. Barnsley (1983) reported the naphthalene dioxygenase, the first key enzyme of naphthalene degradation from Psudomonas sp. and showed that salicylate is the inducer of this enzyme. Smith et al. (2006) described the metabolism of naphthalene by a strain of Mycobacterium sp. involves both monooxygenation and dioxygenation with the formation of both cis- and trans-1,2-dihydrodiols (the ratio of cis- to trans- diol 25:1). The reaction is catalized by cytochrome P-450 monooxygenase that forms naphthalene 1,2-oxide which is further converted to the trans-diol by an epoxide hydrolase enzyme. However, numerous studies were going on the biodegradation of PAH but still little is known about complete metabolic enzymatic pathways of the biodegradation processes.

\section{Improvement in Rhizosphere Bioremediation}

Although the biodegradative abilities of the bacteria, and the expression and maintenance of bacterial genes in the rhizosphere are extremely important for the effective removal of contaminants in phytorhizoremediation, several other aspects can improve the effectiveness of the process. As mentioned previously, the root exudate composition changes with the developmental stage of the plant and depends on plant species; these variations obviously exert different effects on the rhizospheric community (Smalla et al., 2001; Berg et al., 2002; Garbeva et al., 2004). Salix sp. plants are used in many phytorhizoremediation experiments because they produce salicylic acid and related compounds that induce the degradation of PAHs and PCBs (de Cárcer et al., 2007). Flavonoids are produced by plants as a defence mechanism against pathogens. However, plants with a higher content of flavonoids will be efficiently colonized by tolerant bacteria (Palumbo et al., 1998). The root exudate composition will also favour proliferation of bacteria that will degrade them efficiently for e.g. Pseudomonas putida PML2 can grow using plant flavonoids (it is also a PCB degrader) and it has been demonstrated that it colonizes the rhizosphere of wild-type Arabidopsis thaliana (or a mutant that overproduces flavonoids) better than the rhizosphere of a mutant that does not produce flavonoids (Narasimhan et al., 2003). Rhizospheric bacteria can be better equipped to colonize the rhizosphere and are the best option for degradation. Shim et al. (2000) introduced the toluene $o$-monooxygenase genes (TOM) from $B$. cepacia G4 into several bacteria isolated from the poplar rhizosphere and they showed that when they introduced recombinant strains to coat poplar tree roots in non-sterile soil, recombinants that were derived from the plant rhizosphere were able to thrive, while non-rhizospheric recombinant strains were not maintained in the rhizosphere. These strains were also able to express the TOM and degrade trichloroethylene (TCE). Selection of rhizobacteria, which are able to produce biosurfactants in the rhizosphere of the plants, is an interesting alternative to improve the removal efficiency (Plociniczak et al., 2011).

\section{Future Outlook for PMI in Rhizoremediation}

Further studies on improving the expression of catabolic genes in the rhizosphere and in the selection of the best plant-microbe combinations will have to be translated into field strategies that can demonstrate the benefits of this approach. The utilization of endophytes in the biodegradation of pollutants is an emerging field that has not been widely explored. Advances in this field will have to be followed by better knowledge about the biotransformation and bioaccumulation of contaminants together with disposal of contaminated biomass and transport of the toxic chemical by plants. However, this can pose a problem if the compound is then translocated to the shoot where it can become available to animals and humans. The fate of contaminants should be extensively studied during rhizoremediation processes to avoid undesired effects if field tests are performed. Exploring the molecular communication between plants and microbes, and exploiting this communication to achieve better results in the elimination of contaminants, is a fascinating area of research. These studies may reveal the mechanisms of plant- microbe interactions and we predict that this approach will now be adopted to study the induction of catabolic pathways in polluted soils undergoing rhizoremediation. The new genomics techniques will also allow the monitoring or selection of catabolic genes to improve remediation strategies (Kiely et al., 2006) The improvement of metagenomic analysis will probably reveal new degradative capacities (genes) that will be worth introducing into strains with other interesting traits (i.e. good root colonization abilities). The signals that plant and microbes exchange when they recognize each other will have to be interpreted and the molecular basis of the specific interactions between certain plant genotypes with specific bacteria will need to be dissected. Non-cultivation based molecular techniques for detecting microbial genes in environmental samples are considered a powerful tool to study the presence of a PAH-transforming bacterial community. These technologies allowed the discovery of genes encoding the metabolism and catabolism of various constituents of PAHs that would otherwise be impossible by traditional culture techniques. Furthermore, as mentioned earlier (Sayler and Rip, 2000), the marriage of modern recombinant DNA technology and the chemical industries may produce new strains capable of not only broad hydrocarbon metabolism, but also adaptability to contaminated environments (van Hamme et al., 2003). The studies pertaining to molec- 
ular signaling meachanism for biodegradation are still missing in literature. Information that can be derived from these studies may provide further insights on how to design a successful rhizoremediation strategy. Finally, more studies about the impact of using recombinant microorganisms over indigenous microbial communities are needed to meet with safety requirements, especially with the increasing need for recombinant microbes to deal with highly toxic chemicals, such as PAHs and PCBs.

\section{Conclusion}

Bioremediation is recognized as a suitable tool to restore PAH contaminated sites. The synergistic use of plant and associated microbial communities for bioremediation resulting in rhizoremediation, could solve some of the problems encountered during the application of both individual techniques i.e. bioaugmentation and phytoremediation. Although the studies described above clearly indicate the significance of rhizoremediation of PAHs from other remediation strategies and also analyze certain environmental factor that may influence this rhizormediation technique. However, reports about the actual selection of a suitable plant- microbe pair for rhizoremediation system, consisting of a plant inoculated with a bacterium or a consortium with different degradation capacity are in scarce. Therefore, further studies of the selection of suitable rhizosphere bacteria or communities, able to sustain and proliferate on the root system of a plant which is suitable for rhizoremediation or phytoremediation, can yield useful novel (engineered) systems. These systems then can be an interesting tool to further improve and develop bioremediation into a widely accepted technique.

\section{Acknowledgement}

The authors are grateful to G.B. Pant Institute of Himalayan Environment and Development, Ministry of Environment and Forest, Govt. of India for financial support. The authors are also thankful to SBS PG Institute of Biomedical Sciences and Research, Balawala Dehradun for their laboratory facility. Involvement and concern of Dr. Anita Pandey, Senior Scientist, GBPIHED, India, is greatly acknowledged.

\section{References}

Aitken MD, Stringfellow WT, Nagel RD et al. (1998) Characteristics of phenanthrene-degrading bacteria isolated from soils contaminated with polycyclic aromatic hydrocarbons. Can J Microbiol 44:743-752.

Anderson TA, Guthrie EA, Walton BT (1993) Bioremediation in the rhizosphere. Env Sci Technol 27:2630-2636.

Annweiler E, Richow HH, Antranikian G et al. (2000) Napthalene degradation and incorporation of naapthalene- derived carbon into biomass by the thermophilic Bacillus thermoleovarans. Appl Environ Microbiol 66:518-523.
Aprill W, Sims RC (1990) Evaluation of the use of prairie grasses for stimulating polycyclic aromatic hydrocarbon treatment in soil. Chemos 20:253-265.

Arthur EL, Perkovich BS, Anderson TA et al. (2000) Degradation of an atrazine and metolachlor herbicide mixture in pesticidecontaminated soils from two agrochemical dealerships in Iowa. Wat Air Soil Pollut 119:75-90.

Banks MK, Lee E, Schwab AP (1999) Evaluation of dissipation mechanisms for benzo[a]pyrene in the rhizosphere of tall fescue. J Env Qual 28:294-298.

Barea JM, Pozo MJ, Azcón R et al. (2005) Microbial co-operation in the rhizosphere. J Exp Bot 56:1761-1778.

Barnsley EA (1983) Bacterial oxidation of naphthalene and phenanthrene. J Bacteriol 153:1069-1071.

Berg G, Roskot N, Steidle A et al. (2002) Plant-dependent genotypic and phenotypic diversity of antagonistic rhizobacteria isolated from different Verticillum host plants. Appl Environ Microbiol 68:3328-3338.

Binet P, Portal JM, Leyval C (2000) Dissipation of 3e6-ring polycyclic aromatic hydrocarbons in the rhizosphere of ryegrass. Soil Biol Biochem 32:2011-2017.

Bisht S, Pandey P, Sood A et al. (2010) Biodegradation of anthracene and napthlene by chemotactically active rhizobacteria of Populus deltoids. Braz J Microbiol 41:922-930.

Bisht, S, Pandey, P, Aggarwal, H et al. (2014) Utilization of endophytic strain Bacillus sp. SBER3 for biodegradation of polyaromatic hydrocarbons $(\mathrm{PAH})$ in soil model system. European J Soil Biol 60:67-76.

Bodelier PLE, Roslev P, Henckel T et al. (2000) Stimulation by ammonium-based fertilizers of methane oxidation in soil around rice roots. Nat 403:421-424.

Boyajian GE, Carreira LH (1997) Phytoremediation: A clean transition from laboratory to marketplace? Nat Biotechnol 15:127-128.

Brazil GM, Kenefick L, Callanan M et al. (1995) Construction of a rhizosphere Pseudomonad with potential to degrade polychlorinated biphenyls and detection of $b p h$ gene expression in the rhizosphere. Appl Environ Microbiol 61:1946-1952.

Caballero A, Lázaro JJ, Ramos JL et al. (2005) A PnrA, a new nitroreductase family enzyme in the TNT-degrading strain Pseudomonas putida JLR11. Environ Microbiol 7:12111219.

Cai M, Xun L (2002) Organization and regulation of pentachlorophenol-degrading genes in Sphingobium chlorophenolicum ATCC 39723. J Bacteriol 184:46724680.

Canadian Council of Ministers of the Environment (CCME) (2001) Canada-Wide Standards for Petroleum Hydrocarbons (PHC) in Soil, http://www.ccme.ca/assets/pdf/phc_standard_1.0_e.pdf

Cerniglia CE (1984) Microbial metabolism of polycyclic aromatic hydrocarbons. Adv Appl Microbiol 30:31-71.

Cerniglia CE (1997) Fungal metabolisms of polyaromatic hydrocarbons; past, present and future implication in bioremediation. J Ind Microbiol Biotechnol 19:324-333.

Cerniglia CE, Heitkamp ME (1987) Microbial degradation of polycyclic aromatic hydrocarbon $(\mathrm{PAH})$ in the acquatic environment In: U. Vaanasi (ed) Metabolism of Polycyclic Aromatic Hydrocarbon in the Aquatic Environment. CRC Press, Inc. Boca Raton, pp 41-68. 
Chaudhry Q, Blom-Zandstra M, Gupta S et al. (2005) Utilising the synergy between plants and rhizosphere microorganisms to enhance breakdown of organic pollutants in the environment. Env Sci Pollut Res 12:34-48.

Daane JLL, Zylstra IGJ, Aggblom MM (2001) Isolation and characterization of polycyclic aromatic hydrocarbon-degrading bacteria associated with the rhizosphere of salt marsh plants. Appl Environ Microbiol 67:2683-2691.

Dagher F, Deziel E, Lirette P et al. (1997) Comparative study of five polycyclic aromatic hydrocarbon degrading bacterial strains isolated from ontamnated soils. Canadian J Microbiol 43:368 -377.

Davies JI, Evans WC (1964) Oxidative metabolism of naphthalene by soil pseudomonades. The ring fission mechanisms. Biochem J 91:91.

de Cárcer D, Martín M, Karlson U et al. (2007) Changes in bacterial populations and in biphenyl dioxygenase gene diversity in a polychlorinated biphenyl-polluted soil after introduction of willow trees for rhizoremediation. Appl Environ Microbiol 73:6224-6232.

de Weert S, Vermeiren H, Mulders IHM et al. (2002) Flagelladriven chemotaxis towards exudate components is an important trait for tomato root colonization by Pseudomonas $f l$ uorescens, Mol Plant Microbe Int 15:1173-1180.

Dean-Ross D, Moody J, Cerniglia CE (2002) Utilization of mixtures of Polycyclic aromatic hydrocarbons by bacteria isolated from contaminated sediment. FEMS Microbiol Ecol 41:1-7.

Dekkers LC, Mulders IHM, Phoelich CC et al. (2000) The sss colonization gene of the tomato-Fusarium oxysporum $\mathrm{f}$. radicis-lycopersici biocontrol strain Pseudomonas $f l$ uorescens WCS365 can improve root colonization of other wild-type Pseudomonas spp. Bacteria. Mol Plant Microbe Int 13:1177-1183.

Dua M, Sethunathan N, Johri AK (2002) Biotechnology and biormediation: success and limitations. Appl Microbiol Biotechnol 59:143-152.

Farnet AM, Criquet S, Tagger S et al. (2000) Purification, partial characterization, and reactivity with aromatic compounds of two laccases from Marasmius quercophilus strain 17. Can J Micobiol 46:189-194.

Fawell JK, Hunt S (1988) The Polyaromatic hydrocarbons. In: JK Fawell, S, Hunt (eds) Enviormental Toxicology: Organic Pollutants. Ellis Harwood, West Sussex, pp. 241-269.

Filonov AE, Puntus IF, Karpov AV et al. (2006) Assessment of naphthalene biodegradation efficiency of Pseudomonas and Burkholderia strains tested in soil model systems. J Chem Technol Biotechnol 81:216-224.

Garbeva P, Van Veen JA, Van Elsas JD (2004) Microbial diversity in soil: selection of microbial populations by plant and soil type and implications for disease suppressiveness, Ann Rev Phytopathol 42:243-270.

Gentry TJ, Rensing C, Pepper LI (2004) New Approaches for Bioaugmentation as a Remediation Technology. Crit Rev Env Sci Technol 34:447-494.

Gregory PJ, Atwell BJ (1991) The fate of carbon in pulse labeled crops of barley and wheat. Plant Soil 136:205-210.

Harvey PJ, Campanella BF, Castro PM et al. (2002) Phytoremediation of polyaromatic hydrocarbons, anilines and phenols. Env Sci Pollut Res Int 9:29-47.
Hedlund BP, Staley JT (2006) Isolation and characterization of Pseudoalteromonas strains with divergent polycyclic aromatic hydrocarbon catabolic properties. Environ Microbiol 8:178-182.

Heitkamp MA, Franklin W, Cerniglia CE (1988) Microbial metabolism of Polycyclic Aromatic Hydrocarbons: isolation and characterization of a Pyrene-degrading bacterium. Appl Environ Microbiol 54:2549-2555.

Heyndrickx M, Vandemeulebroecke K, Scheldeman P et al. (1995) Paenibacillus (formerly Bacillus) gordonae (Pichinoty et al., 1986) Ash et al., 1994 is a later subjective synonym of Paenibacillus (formerly Bacillus) validus (Nakamura 1984) Ash et al., 1994: emended description of P. validus. Int J Sys Bacteriol 45:661-669.

Huang X-D, El-Alaw YS, Gurska IJ et al. (2005) A multi-process phytoremediation system for decontamination of persistent total petroleum hydrocarbons (TPHs) from soils. Microchem J 8:139-147.

Huang XD, El-Alawi YS, Penrose D et al. (2004) A multiprocess phytoremediation system for removal of polycyclic aromatic hydrocarbons from contaminated soils. Env Pollut 130:465-476.

International Agency for Research on Cancer (1983) Benzo[a]pyrene, Polynuclear Aromatic Compounds, Part 1, Chemical, Environmental and Experimental Data. Monographs on the Evaluation of the Carcinogenic Risk of Chemicals to Humans, vol. 32. IARC, Lyon, pp 211-224.

Jacobsen CS (1997) Plant protecton and hizosphere colonization of barley by seed inoculating herbicide degrading bacteria Burkholderia (Pseudomonas) cepacia DBO1(pRO101) in 2,4-D contaminated soil. Plant Soil 189:139-144.

Juhasz AL, Naidu R (1996) Bioremediation of high molecular weight polycyclic aromatic hydrocarbons: a review of the microbial degradation of benzo[a]pyrene. International $\mathrm{J}$ of Biodet Biodeg 45:57-88.

Kanaly RA, Harayama S (2000) Biodegradation of High molecular weight polycyclic aromatic hydrocarbons by bacteria. $\mathrm{J}$ Bacteriol 182:2059-2067.

Kaplan O, Vejvoda V, Plihal O et al. (2006) Purification and characterization of a nitrilase from Aspergillus niger K10. Appl Microbiol Biotechnol 73:567-575.

Khindaria A, Grover TA, Aust SD (1995) Reductive dehalogenation of aliphatic halocarbons by lignin peroxidase of Phanerochaete chrysosporium. Env Sci Technol 29:719725.

Kiely PD, Haynes JM, Higgins CH et al. (2006) Exploiting new systems-based strategies to elucidate plant-bacterial interactions in the rhizosphere. Microbiol Ecol 51:257.

Kim SJ, Jones RC, Cha CJ et al. (2004) Identification of proteins induced by polycyclic aromatic hydrocarbon in Mycobacterium vanbaalenii PYR-1 using two-dimensional polyacrylamide gel electrophoresis and de novo sequencing methods. Proteomics 4:3899-3908.

Kingsley MT, Fredrickson JK, Metting FB et al. (1994) Environmental restoration using plant-microbe bioaugmentation. In: R.E. Hinchee, A. Leeson, L. Semprini, S.K. Ong (eds) Bioremediation of Chlorinated and Polyaromatic Hydrocarbon Compounds. Lewis Publishers, Boca Raton, pp 287-292.

Kotterman MJJ, Vis EH, Field JA (1998) Successive mineralization and detoxification of Benzo[a]pyrene by the white rot 
fungus Bjerkandera sp. Strain BOS55 and indigenous microflora. Appl Environ Microbiol 64:2853-2858.

Kravchenko C, Mulders M, Phoelich I et al. (1997) Towards the molecular basis of plant root colonization by Pseudomonas bacteria, In: Pseudomonas'97, VI International Congress on Pseudomonas: Molecular Biology and Biotechnology, Madrid.

Kuiper EL, Lagendijk GV, Lugtenberg B (2004) Rhizoremediation: A beneficial plant microbe interaction. Mol Plant Microbe Int 17:6-15.

Kuiper I, Bloemberg GV, Lugtenberg BJJ (2001) Selection of a plant-bacterium pair as a novel tool for rhizostimulation of polycyclic aromatic hydrocarbon-degrading bacteria. Mol Plant Microbe Int. 14:1197-1205.

Kuiper I, Kravchenko L, Bloemberg GV et al. (2002) Pseudomonas putida strain PCL1444, selected for effi cient root colonization and naphthalene degradation, effectively utilizes root exudates components. Mol Plant Microbe Int 15:734741.

Leigh MB, Fletcher JS, Fu X et al. (2002) Root turnover: an important source of microbial substrates in rhizosphere remediation of recalcitrant contaminants. Environ Sci Technol 36:1579-1583.

Leigh MB, Prouzova P, Macek MT et al. (2006) Polychlorinated biphenyl (PCB)-degrading bacteria associated with trees in a PCB contaminated site. Appl Environ Microbiol 72:23312342.

Liste HHM (2000) Plant-promoted pyrene degradation in soil. Chemos 40:7-10.

Liu L, Jiang C-Y, Liu X-Y et al. (2007) Plant-microbe association for rhizoremediation of chloronitroaromatic pollutants with Comamonas sp. strain CNB-1. Environ Microbiol 9:465473.

Lugtenberg BJJ, de Weger LA (1992) Plant root colonization by Pseudomonas spp. In: Galli E, Silver S, Witholt B (eds) Pseudomonas: Molecular Biology and Biotechnology. American. Soc. Microbiol, Washington, D.C., pp. 13-19.

Machado AEH, Furuyama AM, Falone SZ et al. (2000) Photocatalytic degradation of lignin and lignin models, using titanium dioxide: the role of hydroxyl radical. Chemos 40:115-124.

Mackay D, Shiu WY, Ma KC (1991) Illustrated Handbook of Physical-Chemical Properties and Environmental Fate for Organic Chemicals. Lewis Publishing, Boca Raton.

Mackova M, Dowling D, Macek T (2006) Phytoremediation and Rhizoremediation. Springer, Netherlands, $290 \mathrm{pp}$.

Marschner H (2001) Mineral Nutrition of Higher Plants. Academic Press, London 889.

McLean KJ, Sabri M, Marshall KR et al. (2005) Biodiversity of cytochrome P450 redox systems. Biochemistry Soceity Trans 33:796-801.

Meador JP, Stein JE, Reichert WL et al. (1995) Bioaccumulation of polyaromatic hydrocarbon by marine organisms. Review of Env Cont Toxicol 79:143-145.

Mena-Benitez GL, Gandia-Herrero F, Graham S et al. (2008) Engineering a catabolic pathwayin plants for the degradation of 1,2-dichloroethane. Plant Physiol 147:1192-1198.

Meyer Mose R, Neef A, Stahl U et al. (1999) Differential detection of key enzymes of polyaromatic-hydrocarbon-degrading bacteria using PCR and gene probes. Microbiol 145:1731-1741.
Moody JD, Freeman JP, Doerge DR et al. (2001) Degradation of phenanthrene and anthracene by cell suspensions of Mycobacterium sp. strains PYR- 1. Appl Environ Microbiol $67: 1476$

Muratova Hübner T, Narula N, Wand H et al. (2003) Rhizosphere microflora of plants used for the phytoremediation of bitumen-contaminated soil. Microbiol Res 158:151-161.

Narasimhan K, Basheer C, Bajic VB et al. (2003) Enhancement of plant microbe interactions using rhizosphere metabolomics driven approach and its applications in the removal of polychlorinated biphenyls. Plant Physiol 132:146-153.

Narasimhan K, Basheer C, Bajic VB et al. (2003) Enhancement of plant-microbe interactions using a rhizosphere metabolomics-driven approach and its application in the removal of polychlorinated biphenyls. Plant Physiol 132:146-153.

Nichols TD, Wolf DC, Rogers HB et al. (1997) Rhizosphere microbial populations in contaminated soils. Water Air Soil Pollut 95:165-178.

Novotny C, Vyas BRM, Erbanova P et al. (1997) Removal of $\mathrm{PCBs}$ by various white rot fungi in liquid cultures. Folia Microbiologia 42:136-140.

Ortega-Calvo JJ, Marchenko AI, Vorobyov AV et al. (2003) Chemotaxis in polycyclic aromatic hydrocarbon-degrading bacteria isolated from coal-tar- and oil-polluted rhizospheres. FEMS Microbiol Ecol 44:373-381.

Palumbo JD, Kado CI, Phillips DA (1998) An isoflavonoidinducible efflux pump in Agrobacterium tumefaciens is involved in competitive colonization of roots. J Bacteriol 180:3107-3113.

Pandey P, Maheshwari DK (2007) Two-species microbial consortium for growth promotion of Cajanus cajan. Curr Sci 92:1137-1142.

Paquin D, Ogoshi R, Campbell S et al. (2002) Bench-scale phytoremediation of polycyclic aromatic hydrocarboncontaminated marine sediment with tropical plants. Int J Phytorem 4:297-313.

Parales RE, Ditty JL, Harwood CS (2000) Toluene-degrading bacteria are chemotactic towards the environmental pollutants benzene, toluene, and trichloroethylene. Appl Environ Microbiol 66:4098-4104.

Paul D, Pandey GJ, Jain RK et al. (2005) Accessing microbial diversity for bioremediation and environmental restoration. Trends Biotechol 23:135-142.

Pelz O, Tesar M, Wittich RM et al. (1999) Towards elucidation of microbial community metabolic pathways; unraveling the network of carbon sharing in a pollutant degrading bacterial consortium by immunocapture and isotopic ratio mass spectrometry. Environ Microbiol 1:167-174.

Pichinoty F, Waterbury JB, Mandel M et al. (1986) Bacillus gordonae sp. nov., une nouvelle espace appartenant au second groupe morphologique, degrandant divers composes aromatiques. Ann Inst Pasteur Microbiol (Paris) 137A:6578.

Pieper DH, Martins dos Santos VAP, Golyshin PN (2004) Genomic and mechanistic insights into the biodegradation of organic pollutants. Curr Opinion Biotechnol 15:215-224.

Pilon-Smits E (2005) Phytoremediation. Ann Rev Plant Biol $56: 15-39$.

Plociniczak MP, Plaza GA, Seget ZP et al. (2011) Environmental applications of biosurfactants: Recent advances. Int J Mol Sci 12:633-654. 
Qiu X, Shah SJ, Kendall EW et al. (1994) Grass enhanced bioremediation for clay soils contaminated with polynuclear aromatic hydrocarbons In: TA Anderson and JR Coates (eds) Bioremediation Through Rhizosphere Technology. American Chemical Society, Washington, D.C., pp 142-157.

Radvan S, Sorkhoh N, El Nemr L (1995) Oil biodegradation around roots. Nat 376-302.

Rahman KS, Rahman TP, Banat IM (2002) Occurrence of crude oil degrading bacteria in gasoline and diesel station soils. J Basic Microbiol 42:284-291.

Ramadan MA, Tayeb OM, Alexander M (1990) Inoculation size as a factor limiting success of inoculation for biodegradation. Appl Environ Microbiol 56:1392-1396.

Reed MLE, Glick BR (2005) Growth of canola (Brassica napus) in the presence of plant growth-promoting bacteria and either copper or polycyclic aromatic hydrocarbons. Can J Microbiol 51:1061-1069.

Rehmann K, Noll HP, Steiberg CEW et al. (1998) Pyrene degradation by Mycobacterium sp. Strain KR2. Chemos 36:2977-2992.

Rentz JA, Chapman B, Alvarez PJJ et al. (2003) Stimulation of hybrid poplar growth in petroleum contaminated soils through oxygen addition and soil nutrient amendments. Int J Phytorem 5:57-72.

Romero MC, Cazau MC, Giorgieri S et al. (1998) Phenanthrene degradation by microorganisms isolated from a contaminated stream. Env Pollut 101:355-359.

Ronchel MC, Ramos JL (2001) Dual system to reinforce biological containment of recombinant bacteria designed for rhizoremediation. Appl Environ Microbiol 67:2649-2656.

Ruma R, Raja R, Ranjana C et al. (2007) Degradation of polyaromatic hydrocarbons by mixed culture isolated from oil contaminated soil-A bioprocess engineering study. Indian J Biotechnol 6:107-113.

Salt DE, Smith RD, Lakshmanaperumalsamy I et al. (1998) Phytoremediation. Ann Rev Plant Physiol 49:643-668.

Sayler GS, Rip S (2000) Field Applications of Genetically engineered microorganisms for bioremediation processes. Curr Opin Biotechnol 11:286.

Schnoor JL, Aitchison EW, Kelley SL et al. (1998) Phytoremediation and ioaugmentation of 1,4- dioxane. Abstract Advances Biology Rern Systematic Conference 87:91-133.

Schutzendubel Majcherczyk A, Johannes C, Huttermann A (1999) Degradation of Fluorene, anthracene, phenanthrene, fluoranthene, and pyrene lacks connection to the production of extracellular enzymes by Pleurotus ostreatus and Bjerkandera adusta. Int Biodet Biodeg 43:93-100.

Schwab AP, Banks MK (1994) Biologically mediated dissipation of polyaromatic hydrocarbons in the root zone. In: TA Anderson and JR Coats (eds) Bioremediation Through Rhizosphere Technology. American Chemical Society Washington, D.C., pp. 132-141.

Schwab AP, Banks MK, Arunachalam M (1995) Biodgradation of polyaromatic hydrocarbon in rhizosphere. In: RE Hinchee, DB Anderson, RE Hoeppel (eds) Bioremediation of Recalciterant Organics. Battle Memorial Institute, Colombus, pp 23-29.

Shah QX, Kendall SJ, Sorensen EWDL et al. (1994) Grass enhanced bioremediation for clay soils contaminated with polynuclear aromatic hydrocarbons In: TA Anderson and JR Coates (eds) Bioremediation Through Rhizosphere Tech- nology. American Chemical Society, Washington, D.C., pp. 142-157.

Shim H, Chauhan S, Ryoo D et al. (2000) Rhizosphere competitiveness of trichloroethylene-degrading, poplar-colonizing recombinant bacteria. Appl Environ Microbiol 66:46734678.

Shuttleworth KL, Cerniglia CE (1995) Environmental aspects of PAH biodegradation. Appl Biochem Biotechnol 54:291302.

Sikkema J, De Bont JAM, Poolman B (1995) Mechanism of memberane toxicity of hydrocarbons. Microbial Review 59:201-222.

Singh OV, Jain RK (2003) Phytoremediation of toxic aromatic pollutants from soil. Appl Microbiol Biotechnol 63:128135.

Smalla K, Wieland G, Buchner A et al. (2001) Bulk and rhizosphere soil bacterial communities studied by denaturing gradient gel electrophoresis: plant-dependent enrichment and seasonal shifts revealed. Appl Environ Microbiol 67:47424651.

Smith MJ, Flowers TH, Duncan HJ et al. (2006) Effects of polycyclic aromatic hydrocarbons on germination and subsequent growth of grasses and legumes in freshly contaminated soil and soil with aged PAHs residues. Env Pollut 141: 519-525.

Sriprang R, Hayashi M, Yamashita M et al. (2002) A novel bioremediation system for heavy metals using the symbiosis between leguminous plant and genetically engineered rhizobia. J Biotechnol 99:279-293.

Thoma GJ, Lam TB, Wolf DC (2003) A mathematical model of phytoremediation for petroleum contaminated soil: Sensitivity analysis. Int J Phytorem 5:125-136.

Timmis KN, Pieper DH (1999) Bacteria designed for bioremediation. Tibtechnol 17:201-204.

Trzesicka-Mlynarz D, Ward OP (1995) Degradation of polycyclic aromatic hydrocarbons (PAHs) by a mixed culture and its component pure cultures, obtained from $\mathrm{PAH}$-contaminated soil. Can J Microbiol 41:470-476.

Tsuda M, Iino T (1990) Naphthalene degrading genes on plasmid NAH7 are on a defective transposon. Mole Gene Genet 223:34-39.

U.S. EPA (1999) Use of monitored natural attenuation at superfund, RCRA Corrective Action, and underground storage tank sites. Federal Register 64:25039-25040.

Van Aken B, Stahl JD, Naveau H et al. (2000) Transformation of 2, 4, 6-trinitrotoluene (TNT) reduction products by lignin peroxidase (H8) from the white-rot basidiomycete Phanerochaete chrysosporium. Biorem J 4:135-145.

Van Hamme JD, Singh A, Ward OP (2003) Recent Advances in petroleum microbiology. Microbiol Mol Rev 67:649.

Verrhiest GJ, Clement B, Volat B et al. (2002) Interactions between a polycyclic aromatic hydrocarbon mixture and microbial communities in a natural freshwater sediment. Chemos 46:187-196.

Walter U, Beyer M, Klein J et al. (1991) Degradation of pyrene by Rhodococcus sp. UW1. Appl Microbiol Biotechnol 34:671676.

Walton BT, Anderson TA (1990) Microbial degradation of trichloroethylene in the rhizosphere: Potential application to biological remediation of waste sites. Appl Environ Microbiol 56:1012-1016. 
Walton BT, Guthrie EA, Hoylman AM (1994) Toxicant degradation in the rhizosphere. In: TA Anderson, JR Coats (eds) Bioremediation Through Rhizospere Technology. ACS Series 563, Washington, D.C., pp. 11-26.

Weyens N, Taghavi S, Barac T, et al. (2009a) Bacteria associated with oak and Ash on a TCE-contaminated site: characterization of isolates with potential to avoid evapotranspiration. Environ Sci Pollut Res Int 16:830-843.

Widada H, Nojiri K, Kasuga T et al. (2002) Molecular detection and diversity of polycyclic aromatic hydrocarbon-degrading bacteria isolated from geographically diverse sites. Appl Environ Microbiol 58:202-209.

Widada J, Nojiri H, Omori T (2001) Recent developments in molecular techniques for identifi cation and monitoring of xenobiotic-degrading bacteria and their catabolic genes in bioremediation. Appl Microbiol Biotechnol 60:45-59.

Wilson SC, Jones KC (1993) Bioremediation of soil contaminated with polynuclear aromatic hydrocarbons (PAHs): a review. Env Pollut 81:229-249.

Wilson SC, Jones KC (1993) Bioremediation of soil contaminated with polynuclear aromatic hydrocarbons (PAHs): a review. Env Pollut 81:229-249.

Working Group on Polycyclic Aromatic Hydrocarbons (WGPAH) (2001) Ambient Air Pollution by Polycyclic Ar- omatic Hydrocarbons: position paper, Annexes. (ec.europa.eu/environment/air/pdf/pp pah.pdf).

Ye B, Siddiqi MA, Maccubbin AE et al. (1996) Degradation of polynuclear aromatic hydrocarbons by Sphingomonas paucimobilis. Environ Sci Technol 30:136-142.

Yee DC, Maynard JA, Wood TK (1998) Rhizoremediation of trichloroethylene by a recombinant, root-colonizing Pseudomonas fluorescens strain expressing toluene orthomonooxygenase constitutively. Appl Environ Microbiol 64:112-118.

Yuan SY, Shiung LC, Chang BV (2002) Biodegradation of polycyclic aromatic hydrocarbons by inoculated microorganisms in soil. Bulletin Env Cont Toxicol 69:66-67

Zalesny Jr RS, Bauer EO, Hall RB et al. (2005) Clonal variation in survival and growth of hybrid poplar and willow in an in situ trial on soils heavily contaminated with petroleum hydrocarbons. Int J Phytorem 7:177-197.

Zhuang X, Chen J, Shim H et al. (2007) New advances in plant growth-promoting rhizobacteria for bioremediation. Env Int 33:406-413.

Associate Editor: Lara Durães Sette

All the content of the journal, except where otherwise noted, is licensed under a Creative Commons License CC BY-NC. 